\title{
A technological acceptance of e-learning tools used in practical and laboratory teaching, according to the European higher education area ${ }^{1}$
}

\author{
M.R. Martínez-Torres ${ }^{\mathrm{a} *}$, S.L. Toral Marín ${ }^{\mathrm{b}}$, F. Barrero García ${ }^{\mathrm{b}}$, S. Gallardo Vázquez ${ }^{\mathrm{b}}$, \\ M. Arias Oliva ${ }^{\mathrm{c}}$ and T. Torres ${ }^{\mathrm{c}}$ \\ ${ }^{a}$ Department of Business Administration and Marketing, University of Seville, Sevilla, Spain; ${ }^{b}$ Department of Electronic \\ Engineering, University of Seville, Sevilla, Spain; ${ }^{c}$ Department of Business Administration, University Rovira $i$ Virgili, \\ Tarragona, Spain
}

\begin{abstract}
The application of scientific tools to analyse the use of Internet-based e-learning tools in academic settings is in general an ignored area. E-learning tools are actually an emergent topic as a result of the new ideas introduced by the European Higher Education Area. Lifelong learning, or the promotion of student initiative, is the new paradigm of a learner-centred education. In this context, e-learning tools can represent an effective way of supporting this new trend in education. Assuming the premise that successful use of these web-based tools depends primarily on a user's behaviour, the objective of this research is to examine the technology acceptance model (TAM) of web-based elearning tools used in practical and laboratory teaching. The research hypotheses derived from this model have empirically been validated using the responses to a survey on e-learning usage among 220 users. These responses have been examined through partial least square. The obtained results strongly support the extended TAM in predicting a student's intention to use e-learning and define a set of external variables with a significant influence in the original TAM variables. Surprisingly, perceived ease of use did not posit a significant impact on student attitude or intention towards e-learning tool usage. Therefore, early evaluation of e-learning material is considered essential to providing a framework for further improvements of the tool.
\end{abstract}

Keywords: e-learning; technology acceptance model; partial least square

\section{Introduction}

On 21 November 2001, the European Commission adopted a communication on making a European Area of Lifelong Learning a reality (European Commission 2001). This communication was jointly presented by Commissioners Reding and Diamantopoulou as a response to the mandate from the Feira European Council 'to identify coherent strategies and practical measures with a view to fostering lifelong learning for all'. In doing so, it makes an important contribution to achieving the strategic goal set at Lisbon for Europe to become the most competitive and dynamic knowledgebased society in the world. The change from a productbased to a knowledge-based economy has resulted in an increased demand for knowledge workers who are capable of higher-order thinking and reasoning to solve intricate problems in the workplace. This requires organisations to educate and train anyone, anytime and from anywhere (Chorng-Shyong et al. 2004). Member States agreed at the Feira European Council, and in the context of the European Employment Strategy, to develop and implement coherent and comprehensive strategies for lifelong learning. The building blocks of such strategies have been set out in order to assist Member States and actors at all levels. The implication of the building blocks is a gradual integration of formal learning environments with a view to making quality learning opportunities accessible for all, on an ongoing basis. The clear message is that traditional systems must be transformed to become much more open and flexible, so that learners can have individual learning pathways, suitable to their needs and interests, and thus genuinely take advantage of equal opportunities throughout their lives. As a consequence, professionals will be able to adapt themselves to labour market needs.

For this task, asynchronous e-learning, defined as instructional content or learning experience delivered or enabled by electronic technologies including the Internet, intranets and extranets (Govindasamy 2002), breaks the limitations of time and space and also creates many benefits, including reduced cost, regulatory compliance, meeting business needs, retraining of employees, low recurring cost and customer support (Gordon 2003). The impact of e-learning is real and it has received fairly extensive attention from practitioners and information system researchers (Ravenscroft and Matheson 2002, Toral et al. 2005).

\footnotetext{
*Corresponding author. Email: rmtorres@us.es
} 
With the rapid change in all types of working environment, there is a need to implement e-learning systems to train people in new technologies, products and services. However, the large investment in e-learning has made user acceptance an increasingly critical issue for technology implementation and management. Although user acceptance received fairly extensive attention in prior research, efforts were needed to examine or validate previous results, especially in different technologies, user populations and/or organisational contexts.

There have been rapid advances in hardware and software capabilities and the problem of under-utilised systems still remains (Weiner 1993, Johansen and Swigart 1996). The Technology Acceptance Model (TAM) (Davis 1989), which was adapted from the Theory of Reasoned Action (Fishbein and Ajzen 1975), has been used as the theoretical basis for many empirical studies of user technology acceptance (Venkatesh and Davis 2000, Seyal et al. 2002). Apparently it is the most promising way to overcome the problem of poorly utilised systems. However, e-learning is relatively new and e-learners are a specific user group. Thus, original TAM variables, that is, Use, Intention of use, Usefulness and Ease of use (Davis 1989) cannot fully reflect e-learners' motives, requiring a search for additional intrinsic motivational factors.

The use of e-learning material can only be justified by its evaluation and it is also the only way to improve its quality (Aitken and Tabakov 2005). As with any new educational tool, e-learning needs to be justified on the grounds of effectiveness and relevance in relation to the students and the professional groups involved in training and education. If students do not see added value in the learning package, they are not likely to translate the learning objectives of these tools into useful knowledge and skills.

Laurillard (1993) states evaluation is an iterative process and should take place at every stage in the design, production and implementation of a new educational intervention. The iterative nature of evaluation should help in making the learning experience more efficient and effective as the feedback is used to improve the material. Before conducting an evaluation it is important to define the aim of this evaluation and how this is going to be achieved.

This paper presents an outline for conducting an evaluation of e-learning material using examples from three different e-learning tools. This study was started to respond both to prior studies' indication of the need for a broader exploration of factors beyond the original TAM (Legris et al. 2003) and to a prior study's suggestion for more examination of the role computer self-efficacy plays in predicting Information Technology (IT) usage behaviour (Chau 2001).

\section{Background}

Users' intention to continue using an e-learning service is considered as a major determinant of e-learning success. While initial use (acceptance) of the e-learning service is the important first step toward realising elearning success, an eventual e-learning success further depends on its continued use or 'continuance' (in contrast to initial use or 'acceptance') after initial use. Clearly, understanding the factors influencing the user's intention to continue using the e-learning service is a critical issue for researchers and practitioners (Chiu et al. 2005).

Within the European Higher Education Area, there is a move towards flexible e-learning as it has been recognised to have a number of benefits. For example, by increasing the access via flexible learning, entrance to courses is extended to those geographically isolated, those whose disability prevents them accessing higher education and those whose particular social and personal circumstances are not conducive to oncampus learning (Wade 1994). Furthermore, it has been reported that traditional lectures are not always rated as the best way to learn (Biggs 1999). Today's students have grown up in a technological age of television, computers and videogames. Some researchers argue that neither students nor teachers regard traditional lectures as effective and students now expect technology to be used effectively as part of their learning experience (Willcoxson 1998, Frey and Birnbaum 2002). The challenge for lecturers has held the attention of students from this high-tech generation. Many authors have suggested designing the learning and teaching environment to promote greater student participation and engagement, thereby increasing deep learning in the students (Biggs 1999, ChaoMin et al. 2005, Toral et al. 2006). Students find e-learning appealing and engaging and may therefore be more involved and motivated as a consequence. However, the uptake of e-learning has been hampered by barriers as identified by the Department for Education and Skills (2003). For example, educational leaders are not yet fully engaged in exploiting e-learning and e-systems as they need more support to enable them to lead and manage the challenging change processes involved. Against this background of potential problems, the framework for expansion and evaluation of e-learning material becomes one of the highest priorities for developers and researchers.

\section{The development model}

The range of research related to learning and teaching using the Internet is unexpectedly broad (Wolfe 2001, Toral et al. 2005). Piccoli et al. (2001) proposed a 
research framework for the assessment of learning outcomes associated with web-based virtual learning environments. Riva (2001) examined social acts in online learning environments, focusing on the creation and maintenance of 'virtual learning communities'. Anderson (2001) applied aptitude - treatment interaction to explore the impact of individual differences on student performance in a web-based course.

The main aim of this research has been the development of a method to evaluate students' adoption of e-learning tools. The theoretical grounding for this research derives from the TAM (Davis 1989). We have adapted it as the basis for our framework to explain student adoption and usage of an e-learning tool. Critical evaluations of it and comparisons with other intention-based models, such as the Theory of Reasoned Action and Theory of Planned Behaviour, have demonstrated that TAM is theoretically customised for the study of computer-technology acceptance with a high research significance in the information system discipline (Thatcher and De La Cour 2003). TAM has been widely used in information system research (e.g. Venkatesh and Davis 2000). Further, TAM is capable of explaining user behaviour across a broad range of end-user computing technologies and user populations, while at the same time being both parsimonious and theoretically justified (Al-Gahtani and King 1999, Lee et al. 2005).

According to previous literature, our technology acceptance model integrates some TAM components in order to provide a better explanation of IT adoption in learning environments. This is based on prior research, which suggested that user acceptance is determined by two key beliefs: perceived usefulness; and perceived ease of use. In addition, some variables have been integrated into TAM to adapt it for the empirical study of e-learning.

In TAM, IT usage is determined by behavioural intention, which, in turn, is affected by attitude toward usage, as well as the direct and indirect effects of perceived usefulness and perceived ease of use. Both of them jointly affect attitude, while perceived ease of use has a direct impact on perceived usefulness. Perceived usefulness refers to 'the degree to which a person believes that using a particular system would enhance his or her performance' (Davis 1989). Perceived usefulness indeed explains the utility values for system usage. This implies that an e-learning system with a high level of perceived usefulness is one for which a user believes that there is a positive user - performance relationship. There is also extensive research in the information system community providing evidence of the effect of perceived usefulness on behavioural intention to use (Venkatesh and Morris 2000). It is a key driver of usage behaviour and intentions. Here, the perceived utility values of the e-learning tools are expected to affect student intention to use it. However, perceived ease of use is the degree to which a person believes that using a particular system would be free of effort. It is expected to influence perceived usefulness and behavioural intention to use. Extensive research over the past decade has provided evidence that perceived ease of use has a significant effect on behavioural intention to use, either directly or indirectly, through its effect on perceived usefulness (Agarwal and Prasad 1999, Venkatesh 1999). Therefore, we hypothesised:

H0: Intention to use will have a positive effect on use.

H1: Perceived usefulness will have a positive effect on the behavioural intention to use e-learning. H2: Perceived ease of use will have a positive effect on perceived usefulness of e-learning.

H3: Perceived ease of use will have a positive effect on behavioural intention to use e-learning.

However, a critical review of TAM (Legris et al. 2003, Wu and $\mathrm{Wu} 2005$ ) has revealed that there is a need to include other components in order to provide a broader view and a better explanation of IT adoption. Specifically, factors related to human and social change processes should be incorporated (Csikszentmihalyi 1993). For instance, Davis et al. (1992) adapted the motivational perspectives and added perceived enjoyment and explained IT acceptance from both extrinsic and intrinsic motivational perspectives. Deci and Ryan (1985) and Venkatesh et al. (2002) also redefined TAM within a motivational framework. The resulting model included both extrinsic and intrinsic motivations as predictors of behavioural intention to use. According to this criticism, we are going to introduce some new variables in our TAM in order to get a better explanation of IT adoption.

E-learning tools provide students with a new channel to learn (Catchpole 1993). Through its use, students may learn in a self-paced and interactive way, feeling more playful and challenging (Atkinson and Kydd 1997). Additionally, through an online chat room and discussion board, students can affiliate with others through pro-social relationships (Bagozzi and Lee 2002, Lee et al. 2005). They may be inherently motivated to feel connected to others. Thus, we can hypothesise:

H4: Interactivity and control will have a positive effect on perceived usefulness of e-learning. H5: Feedback will have a positive effect on interactivity and control. 
H6: Communicativeness will have a positive effect on user adaptation.

From an intrinsic motivational perspective, behaviour is evoked from the feeling of pleasure, joy and fun. Perceived enjoyment is defined as 'the extent to which the activity of using the computer is perceived to be enjoyable in its own right, apart from any performance consequences that may be anticipated'. Therefore, if a student perceives the use of the elearning tool as enjoyable, he or she is more likely to have a favourable feeling towards the e-learning tool and a higher degree of intention to use it. In our study, the effect of perceived enjoyment on perceived ease of use (in the use of e-learning tools) was expected to be positive. According to the self-efficacy theory (Bandura 1977, 1982, Ford 1992), perceived ease of use influences intrinsic motivation. That is, if a student has a higher degree of self-competence (and thus perceives it as easy to use), he/she is more likely to have an enjoyable feeling towards using it. Thus:

H7: There is a positive relationship between enjoyment and ease of use of e-learning.

H8: User tools will have a positive effect on enjoyment.

H9: Diffusion will have a positive effect on enjoyment.

H10: Methodology will have a positive effect on diffusion of e-learning tools.

The concept of facilitating condition is adopted from a resource-based facilitating condition (Ajzen 1991). Resource-based facilitating condition refers to the beliefs about accessibility to resources necessary to facilitate a service (Cheong et al. 2004). When curriculum delivery is principally available at set times and in set places, the opportunities for students with jobs, forwarding commitments, mobility problems and so on to commit themselves to advanced study are limited. Resource-based learning at its best provides ways for students to learn at their own pace, at all times of the day, often in locations convenient to them, and it also provides back-ups for absentees (Pearson and Ford 1997). According to this we can say that:

H11: Reliability will have a positive effect on ease of use of e-learning.

H12: Accessibility will have a positive effect on easy of use of e-learning.

According to Vijay-Rao (2004), the TAM and its variants do not use feedback as an element for sustaining acceptance of new technology. In practice, it is an important mechanism that helps to modify and reinforce those factors that assist in altering perceptions (Delone and Mclean 1992). Many new programs fail after the initial novelty fades and many users relegate new initiatives as "just another flavour of the month' and revert back to their old ways. Feedback should be used as an iterative process for teaching, and training should be continuously modified based on the feedback. A database of 'Lessons learned' will serve to develop targeted promotion and training. Taking it into account, we could hypothesise:

H13: Format will have a positive effect on feedback.

H14: Feedback will have a positive effect on methodology of e-learning.

H15: User adaptation will have a positive effect on feedback.

Figure 1 depicts the research model used in this research.

\section{Research method}

\subsection{Data collection}

Our study aimed at investigating students' adoption of e-learning tools. This study will focus on three elearning tools.

(1) An interactive CD-ROM, which has texts, figures and multimedia that explain the contents of the subject.

(2) A virtual laboratory, through which students can do their laboratory practices thanks to the PC connected through the Internet to a web server with a LabVIEW environment controlling a laboratory test bench. Students can manipulate the laboratory instruments through a GIPB bus, even if they are not physically in the laboratory.

(3) A Learning Management System platform called Edustance, which was created as an Internet learning portal containing lecture notes, chat room facilities and streaming videos of lectures to provide out-of-classroom support to the regular campus-based students.

Students were requested to complete a questionnaire that covered all the measures of the constructs in our research model. A total of 220 usable questionnaires was collected.

\subsection{Measures}

Content validity was measured as follows. Items selected for the constructs were adapted from Davis' 


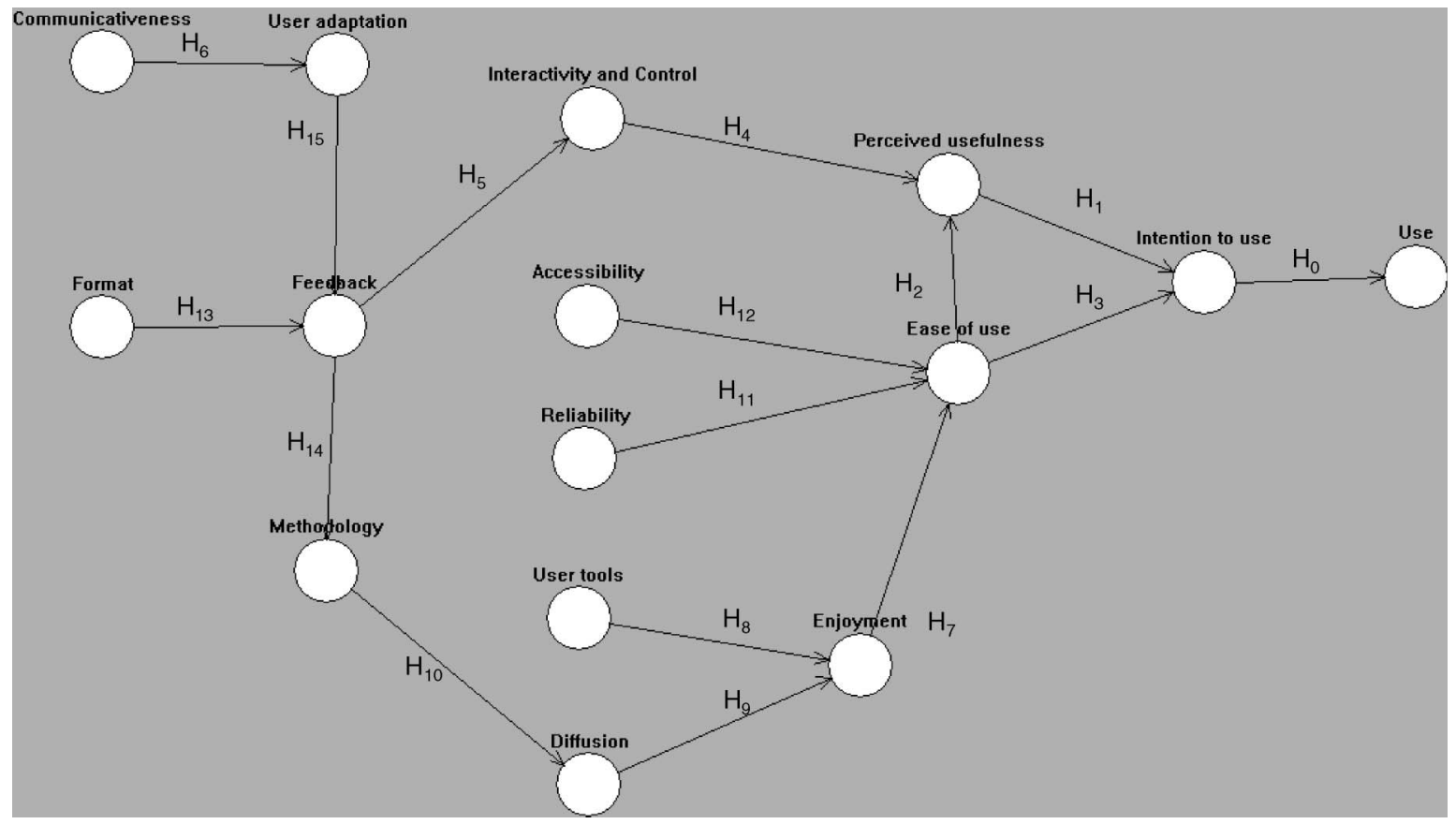

Figure 1. E-learning technology acceptance model.

prior studies with modifications to fit the specific context of the Internet-based learning innovative. The items were modified to make them relevant to the elearning usage context. Measurements for the different constructs of our model were phrased on a 7-point Likert scale, from $1=$ strongly disagree to $7=$ strongly agree. For each item, respondents were asked to circle the response that best described their level of agreement with the statements. Pre-testing and pilot testing of measures were conducted by selected users from the e-learning field, as well as experts in the area. The validated measures of this study are shown in Appendix 1.

\subsection{Data analysis}

Causal and structural equation modelling is a way of assessing the reliability and validity of the measures of theoretical constructs and estimating the relationships among these constructs. According to Chin (1998), if structural equation modelling is accurately applied, it can surpass such first-generation techniques as principle components analysis, factor analysis, discriminant analysis or multiple regressions. Specifically, it provides a greater flexibility in estimating relationships among multiple predictors and criterion variables and allows modelling with unobservable latent variables; it estimates the model uncontaminated with measurement errors. Two approaches to causal modelling that appear in the literature are:

(1) Covariance structure analysis as implemented in LISREL.

(2) Partial least square (PLS).

The basic distinction between PLS and LISREL as causal modelling methodologies rests in their objectives. LISREL is best used for theory testing and development; while PLS is oriented more towards predictive applications (Barclay et al. 1995). LISREL estimates model parameters in an attempt to reproduce the covariance matrix of the measures (or observable variables) and also incorporates overall goodness-of-fit measures to see how well the hypothesised model 'fits' the data (Browne and Cudeck 1993). Covariance structure analysis is 'theory-oriented, and emphasises the transition from exploratory to confirmatory analysis' (Jöreskog and Wold 1982). In comparison with LISREL, PLS has as its objective the explanation of variance in a regression sense and thus $R^{2}$ and the significance of relationships among constructs are measures more indicative of how well a model is performing. 'PLS is primarily intended for causalpredictive analysis in situations of high complexity but low theoretical information' (Jöreskog and Wold 1982). For theses reasons, model testing was examined through PLS framework in our case. 


\section{Results}

Following the two-step analytical procedures (Hair et al. 1998), we first examined the measurement model and then the structural model. The rationale of this twostep approach is to ensure our conclusion on structural relationship is drawn from a set of measurement instruments with desirable psychometric properties.

\subsection{Measurement model}

The measurement model was first evaluated in terms of reliability, internal consistency, convergent validity and discriminant validity. Table 1 summarises the factor loadings, composite reliability and average variance extracted of the measures of our research model.

\subsubsection{Individual item reliability}

In general, one would like to have each indicator share more variance with the component score than with error variance. This implies that standardised loadings should be greater than 0.7 . However, loadings of 0.5 and 0.6 may still be acceptable if there are additional indicators in the block for comparison basis (Chin 1998). This condition was met in this study, as shown in Table 1.

\subsubsection{Internal consistency}

In assessing the internal consistency for a given block of indicators, we have calculated the composite reliability, which should be greater than 0.7 (Nunnally 1978). This condition was also met in this study, as shown in Table 1.

\subsubsection{Convergent validity}

Convergent validity indicates the extent to which the items of a scale that are theoretically related should correlate highly. It was evaluated for the measurement scales using two criteria suggested by Fornell and Larcker (1981): (1) all indicator factor loadings should be significant and exceed 0.7 ; (2) average variance extracted for each construct should exceed the variance due to measurement error for that construct (i.e. should exceed 0.5). Table 1 summarises the factor loadings, composite reliability $(\alpha)$ and average variance extracted $(\rho)$ of the measures of our research model. All the measures fulfil the recommended levels.

\subsubsection{Discriminant validity}

Discriminant validity is the extent to which the measure is not a reflection of some other variable. It
Table 1. Measurement model.

\begin{tabular}{|c|c|c|c|c|}
\hline Construct & $\begin{array}{l}\text { Composite } \\
\text { reliability }\end{array}$ & AVE & Item & Loading \\
\hline Use & 0.915 & 0.844 & $\begin{array}{l}\mathrm{C} 83 \\
\mathrm{C} 84\end{array}$ & $\begin{array}{l}0.8951 \\
0.9419\end{array}$ \\
\hline Intention of use & 0.835 & 0.717 & $\begin{array}{l}\text { C77 } \\
\text { C78 }\end{array}$ & $\begin{array}{l}0.8314 \\
0.8620\end{array}$ \\
\hline Perceived usefulness & 0.947 & 0.751 & $\begin{array}{l}\text { C73 } \\
\text { C74 } \\
\text { C75 } \\
\text { C76 } \\
\text { C72 } \\
\text { C71 }\end{array}$ & $\begin{array}{l}0.9031 \\
0.7151 \\
0.8799 \\
0.8819 \\
0.9070 \\
0.8965\end{array}$ \\
\hline Ease of use & 0.896 & 0.635 & $\begin{array}{l}\text { C65 } \\
\text { C66 } \\
\text { C67 } \\
\text { C68 } \\
\text { C } 70\end{array}$ & $\begin{array}{l}0.8151 \\
0.7618 \\
0.8796 \\
0.8319 \\
0.6802\end{array}$ \\
\hline Methodology & 0.882 & 0.715 & $\begin{array}{l}\text { C7 } \\
\text { C8 } \\
\text { C9 }\end{array}$ & $\begin{array}{l}0.8722 \\
0.7917 \\
0.8698\end{array}$ \\
\hline Accessibility & 0.803 & 0.577 & $\begin{array}{l}\text { C38 } \\
\text { C39 } \\
\text { C40 }\end{array}$ & $\begin{array}{l}0.8520 \\
0.6992 \\
0.7192\end{array}$ \\
\hline Reliability & 0.905 & 0.760 & $\begin{array}{l}\text { C58 } \\
\text { C59 } \\
\text { C60 }\end{array}$ & $\begin{array}{l}0.8675 \\
0.8525 \\
0.8946\end{array}$ \\
\hline Enjoyment & 0.939 & 0.795 & $\begin{array}{l}\text { C48 } \\
\text { C50 } \\
\text { C55 } \\
\text { C56 }\end{array}$ & $\begin{array}{l}0.8263 \\
0.9006 \\
0.9210 \\
0.9158\end{array}$ \\
\hline User adaptation & 0.891 & 0.620 & $\begin{array}{l}\text { C22 } \\
\text { C23 } \\
\text { C25 } \\
\text { C27 } \\
\text { C28 }\end{array}$ & $\begin{array}{l}0.7607 \\
0.7531 \\
0.8018 \\
0.7758 \\
0.8434\end{array}$ \\
\hline Communicativeness & 0.964 & 0.871 & $\begin{array}{l}\text { C29 } \\
\text { C30 } \\
\text { C31 } \\
\text { C32 }\end{array}$ & $\begin{array}{l}0.9543 \\
0.9621 \\
0.9663 \\
0.8455\end{array}$ \\
\hline Feedback & 0.868 & 0.624 & $\begin{array}{l}\text { C12 } \\
\text { C14 } \\
\text { C15 } \\
\text { C16 }\end{array}$ & $\begin{array}{l}0.7062 \\
0.9087 \\
0.7439 \\
0.7853\end{array}$ \\
\hline Format & 0.880 & 0.785 & $\begin{array}{l}\mathrm{C} 2 \\
\mathrm{C} 3\end{array}$ & $\begin{array}{l}0.9071 \\
0.8646\end{array}$ \\
\hline $\begin{array}{l}\text { Interactivity and } \\
\text { control }\end{array}$ & 0.921 & 0.746 & $\begin{array}{l}\text { C44 } \\
\text { C45 } \\
\text { C46 } \\
\text { C47 }\end{array}$ & $\begin{array}{l}0.8500 \\
0.9160 \\
0.9006 \\
0.7824\end{array}$ \\
\hline Diffusion & 0.882 & 0.653 & $\begin{array}{l}\text { C33 } \\
\text { C34 } \\
\text { C35 } \\
\text { C36 }\end{array}$ & $\begin{array}{l}0.7960 \\
0.8513 \\
0.8809 \\
0.6902\end{array}$ \\
\hline User tools & 0.855 & 0.662 & $\begin{array}{l}\text { C61 } \\
\text { C63 } \\
\text { C64 }\end{array}$ & $\begin{array}{l}0.7935 \\
0.8342 \\
0.8129\end{array}$ \\
\hline
\end{tabular}

$\mathrm{AVE}=$ average variance extracted

is indicated by low correlations between the measure of interest and the measures of other constructs. Evidence about discriminant validity of the measures can be verified with the squared root of the average variance 
extracted for each construct higher than the correlations between it and all other constructs (Fornell and Larcker 1981). As summarised in Table 2, the square root of average variance extracted for each construct (on the diagonal) is greater than the correlations between the constructs and all other constructs. The results suggest an adequate discriminant validity of the measurements.

\subsection{The structural model}

The research model was tested using PLS-Graph v.3.0 (Chin 2003). The model was estimated using maximum likelihood method. Figure 2 depicts fit statistics, overall explanatory power and estimated path coefficients.

To assess the statistical significance of the path coefficients, which are standardised betas, a bootstrap analysis was performed. The use of bootstrapping, as opposed to traditional t-tests, allows the testing of the significance of parameter estimates from data that are not assumed to be multivariate normal. In this case 500 sub-samples were created by removing cases from the total dataset. PLS estimates the parameters of each sub-sample and 'pseudo values' are calculated by applying the bootstrap formula. Table 3 shows that most of the paths proved to be significant at the

Table 2. Discriminant validity.

\begin{tabular}{|c|c|c|c|c|c|c|c|c|c|c|c|c|c|c|c|}
\hline & $\mathrm{U}$ & IU & PU & EU & M & A & $\mathrm{R}$ & $\mathrm{E}$ & UA & $\mathrm{C}$ & FB & $\mathrm{F}$ & $\mathrm{IC}$ & $\mathrm{D}$ & UT \\
\hline $\mathrm{U}$ & 0.91 & & & & & & & & & & & & & & \\
\hline IU & 0.34 & 0.84 & & & & & & & & & & & & & \\
\hline PU & 0.21 & 0.55 & 0.86 & & & & & & & & & & & & \\
\hline EU & 0.15 & 0.35 & 0.46 & 0.79 & & & & & & & & & & & \\
\hline M & 0.19 & 0.31 & 0.23 & 0.27 & 0.84 & & & & & & & & & & \\
\hline A & 0.21 & 0.25 & 0.28 & 0.48 & 0.21 & 0.75 & & & & & & & & & \\
\hline $\mathrm{R}$ & 0.13 & 0.34 & 0.37 & 0.55 & 0.29 & 0.40 & 0.87 & & & & & & & & \\
\hline E & 0.22 & 0.31 & 0.40 & 0.29 & 0.13 & 0.16 & 0.19 & 0.89 & & & & & & & \\
\hline UA & 0.33 & 0.37 & 0.31 & 0.18 & 0.42 & 0.20 & 0.23 & 0.57 & 0.78 & & & & & & \\
\hline C & 0.25 & 0.24 & 0.15 & 0.10 & 0.36 & 0.16 & 0.15 & 0.61 & 0.75 & 0.93 & & & & & \\
\hline FB & 0.25 & 0.37 & 0.37 & 0.25 & 0.50 & 0.25 & 0.21 & 0.44 & 0.67 & 0.48 & 0.78 & & & & \\
\hline $\mathrm{F}$ & 0.15 & 0.26 & 0.21 & 0.16 & 0.63 & 0.12 & 0.21 & 0.25 & 0.52 & 0.40 & 0.59 & 0.88 & & & \\
\hline IC & 0.31 & 0.45 & 0.39 & 0.42 & 0.61 & 0.32 & 0.39 & 0.24 & 0.57 & 0.41 & 0.53 & 0.47 & 0.86 & & \\
\hline D & 0.24 & 0.27 & 0.40 & 0.34 & 0.23 & 0.25 & 0.12 & 0.65 & 0.59 & 0.51 & 0.50 & 0.36 & 0.30 & 0.80 & \\
\hline UT & 0.33 & 0.36 & 0.21 & 0.11 & 0.41 & 0.29 & 0.30 & 0.41 & 0.63 & 0.53 & 0.57 & 0.53 & 0.45 & 0.34 & 0.81 \\
\hline
\end{tabular}

$\mathrm{U}=$ use; $\mathrm{IU}=$ intention of use; $\mathrm{PU}=$ perceived usefulness; $\mathrm{EU}=$ ease of use; $\mathrm{M}=$ methodology; $\mathrm{A}=$ accessibility; $\mathrm{R}=$ reliability; $\mathrm{E}=$ enjoyment; $\mathrm{UA}=$ user adaptation; $\mathrm{C}=$ communicativeness; $\mathrm{FB}=$ feedback; $\mathrm{F}=$ format; $\mathrm{IC}=$ interactivity and control; $\mathrm{D}=$ diffusion; $\mathrm{UT}=$ user tools.

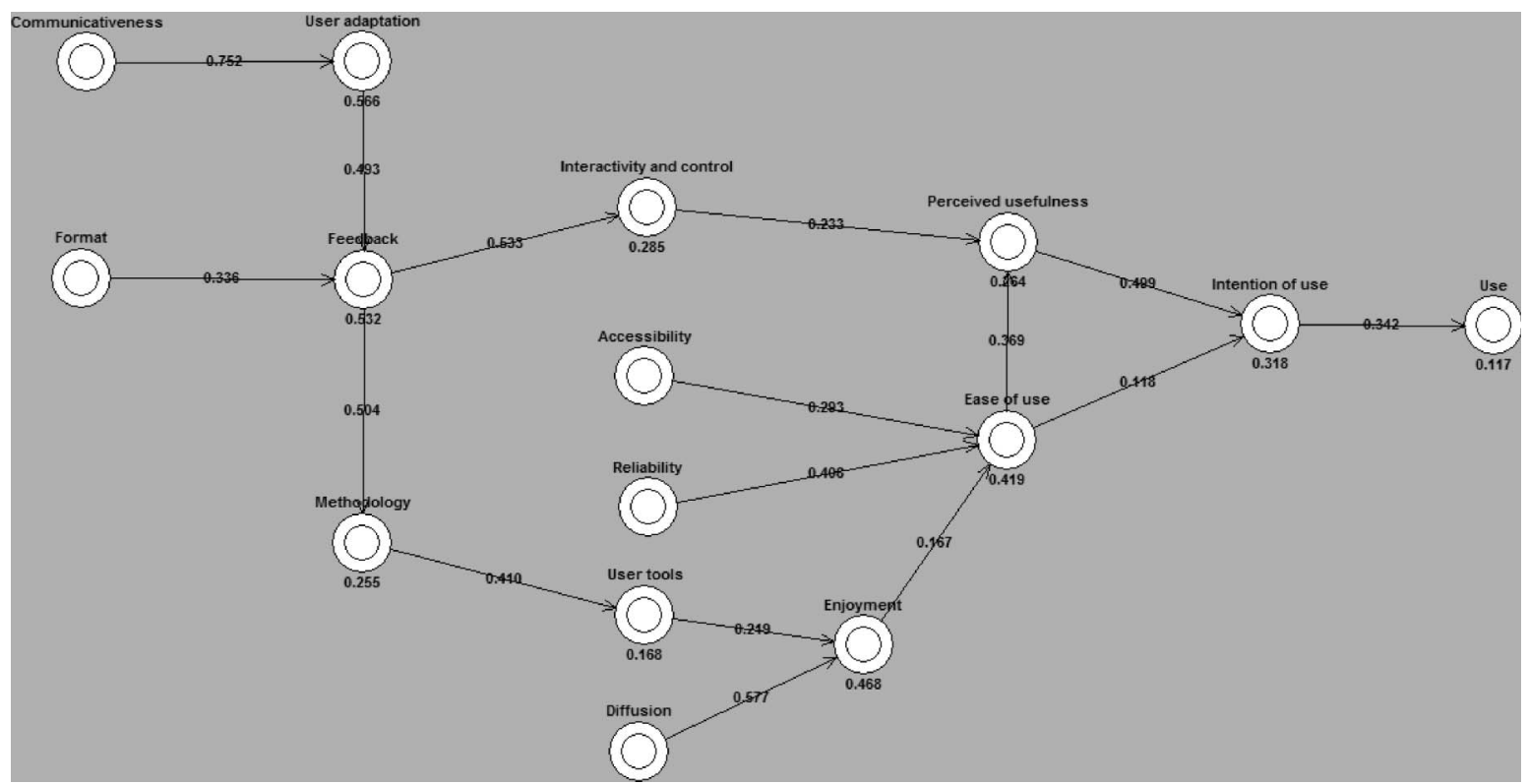

Figure 2. A model of e-learning tool. 


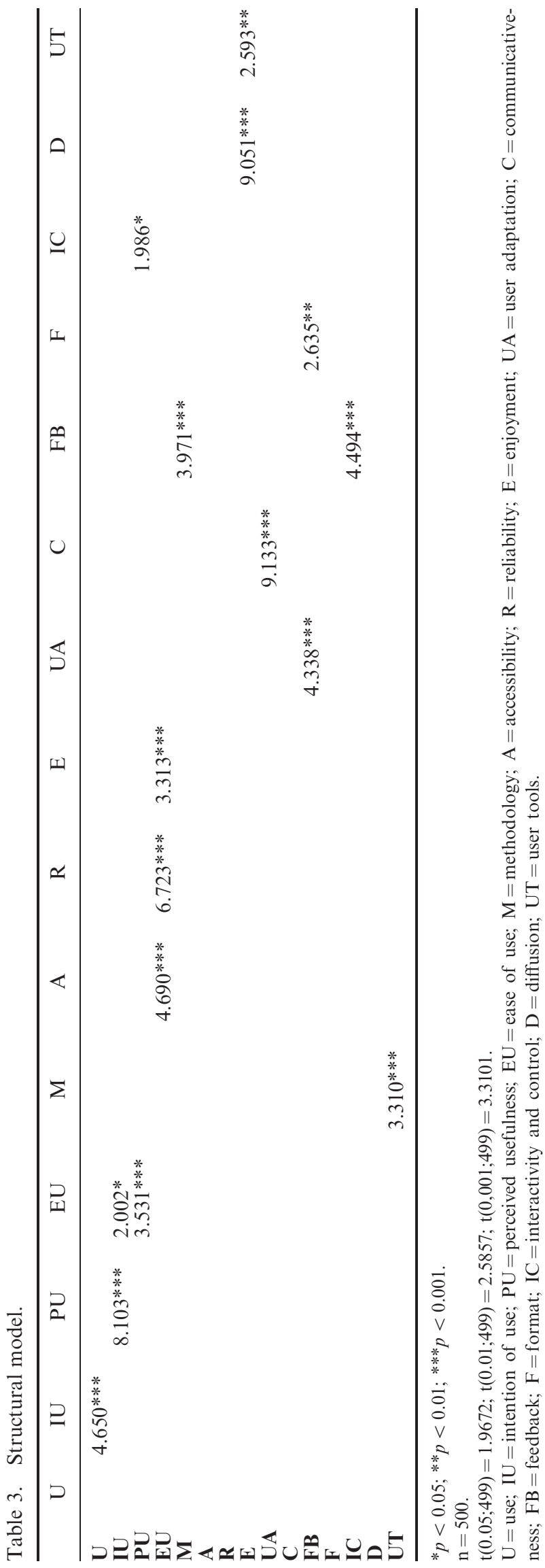

$p$-value $<0.001$ level, two of them $\left(\mathrm{H}_{8}\right.$ and $\left.\mathrm{H}_{13}\right)$ were significant at the $p$-value $<0.01$, and, finally, three of them $\left(\mathrm{H}_{3}\right.$ and $\left.\mathrm{H}_{4}\right)$ were significant at the $p$-value $<0.05$ All the hypotheses were supported.

Finally, the results from the analysis show the explanatory power of the research model. It revealed that the proposed model accounted for $31.8 \%$ of the variance in behavioural intention to use. According to the path coefficients, perceived usefulness exhibited the strongest direct effect on behavioural intention to use. Perceived ease of use, despite showing a slightly weaker direct effect than perceived usefulness on behavioural intention to use, exhibited a stronger total effect on behavioural intention to use than that of perceived usefulness.

\section{Conclusion}

The use of the e-learning material can only be warranted by its evaluation and it is also the only way to improve its quality. The evaluations described in this paper were designed to research the views of student users and training experts on e-learning material.

This paper reports on work where an examination of TAM was carried out against a background of indepth evaluation of three e-learning tools. Using the extended model as a theoretical framework, this study helps practitioners and researchers better understand why people resist using e-learning, predict how users will respond to e-learning and increase user acceptance by improving the techniques and processes by which they are implemented. Also, it can help researchers considerate our findings for development and evaluation of e-learning theories.

Consistent with prior studies (Lee et al. 2005), this study found that all variables except perceived ease of use significantly affected users' behavioural intent. Surprisingly, perceived ease of use did not posit a significant impact on student attitude or intention towards e-learning tool usage. It can be due to the fact that the students have got enough knowledge or previous experience on computers in general, so they are not afraid when using a new computer-based tool.

New factors related to human and social change processes have been integrated to the initial TAM to adapt it for the study of e-learning tools. Some of these factors refer to providing students with a new channel to learn (Interactivity and control, Feedback, Communicativeness); others refer to factors that can affect students' motivations to use the tool (Enjoyment, User tools, Diffusion, Methodology, User adaptation). In accordance with this, the present study has been able to explain a significant amount of variance in intention of use $(31.8 \%)$ but not in actual use $(11.7 \%)$. The results suggest that the research model provided good 
explanatory power of user intention of use. It implies that factors of the extended TAM play important roles in shaping user intention of use and, thus, information system researchers should consider post-usage factors when exploring users' intention of use with the specific technology. The results also suggest that additional constructs would be necessary to enhance the explanatory power of the TAM in predicting use.

Four limitations of this study should be noted:

(1) Researching in acceptance of e-learning is relatively new, so this study should be considered as exploratory in nature.

(2) The findings and their implications are obtained from a study of three particular technologies. Although these three studied cases are quite different, CD-ROM, a remote laboratory and a Learning Management System, caution should be taken when generalising the findings.

(3) Responses were voluntary and thus inevitably subject to self-selection biases. Conceivably, users who were interested in, had used or were currently using e-learning were more likely to respond.

(4) The study was conducted with a snapshot research approach. The test - retest reliability could examine the stability of a construct over time (Webster and Martocchio 1996), which could be evaluated by comparing the scores of the same set of subjects at two different time periods. Additional efforts are needed to evaluate the validity of the proposed model and our findings.

Despite these limitations, this work is both trying to illustrate a way of evaluating e-learning tools that could be extended to similar tools, and to fill the lack of scientific studies about this topic.

\section{Note}

1. This research has been funded by the Spanish Education and Science Ministry, in its Study and Analysis Programme (EA2005 - 0176).

\section{References}

Agarwal, R. and Karahanna, E., 2000. Time flies when you're having fun: cognitive absorption and beliefs about information technology usage. MIS Quarterly, 24 (4), 665-695.

Agarwal, R. and Prasad, J., 1999. Are individual differences germane to the acceptance of new information technologies? Decision Sciences, 30 (2), 361-391.

Aitken, V. and Tabakov, S., 2005. Evaluation of the e-learning material developed by EMERALD and EMIT for diagnostic imaging and radiotherapy. Medical Engineering \& Physics, 27 (7), 633-639.
Ajzen, I., 1991. The theory of planned behaviour. Organizational Behaviour and Human Decision Processes, 50, 179211.

Al-Gahtani, S.S. and King, M., 1999. Attitudes, satisfaction and usage: factors contributing to each in the acceptance of information technology. Behaviour \& Information Technology, 18 (4), 277-297.

Anderson, M.D., 2001. Individual characteristics and webbased courses. In: C.R. Wolfe, ed. Learning and teaching on the world wide web. San Diego, CA: Academic Press, 45-72.

Atkinson, M.A. and Kydd, C., 1997. Individual characteristics associated with worldwide web use: an empirical study of playfulness and motivation. The DATA BASE for Advances in Information Systems, 28 (2), 53-62.

Bagozzi, P.R. and Lee, K.H., 2002. Multiple routes for social influence: the role of compliance, internalization, and social identity? Social Psychology Quarterly, 65 (3), 226247.

Bandura, A., 1977. Self-efficacy: toward a unifying theory of behavioural change. Psychological Review, 84 (2), 191-215.

Bandura, A., 1982. Self-efficacy mechanism in human agency. American Psychologist, 37 (2), 122-147.

Barclay, D., Higgins, C., and Thompson, R., 1995. The partial least squares (PLS) approach to causal modeling: personal computer adoption and use as an illustration. Technology Studies, Special Issue on Research Methodology, 2 (2), 285-309.

Biggs, J., 1999. Teaching for quality learning at university. Buckingham: Society for Research into Higher Education and Open University Press.

Browne, M.W. and Cudeck, R., 1993. Alternative ways of assessing model fit. In: K. Bollen and J.S. Long, eds. Testing structural models. Newbury Park, CA: Sage Publications, 136-162.

Catchpole, M.J., 1993. Interactive media: the bridge between distance and classroom education. In: T. Nunan, ed. Distance education futures. Adelaide: University of South Australia Press, 37-56.

Chao-Min, C., Meng-Hsiang, H., Szu-Yuan, S., Tung-Ching, L., and Pei-Chen, S., 2005. Usability, quality, value and e-learning continuance decisions. Computers \& Education, 45 (4), 399-416.

Chau, P.Y.K., 2001. Influence of computer attitude and selfefficacy on IT usage behaviour. Journal of End User Computing, 13 (1), 26-33.

Cheong, J.H., Park, M.-C., and Hwang, J.H., 2004. Mobile payment adoption in Korea: switching from a credit card. In: Paper presented at the International telecommunications society ITS 15th biennial conference, 4-7 September 2004, Berlin, Germany.

Chin, W.W., 1998. The partial least squares approach to structural equation modeling. In: G.A. Marcoulides, ed. Modern methods for business research. Mahwah, NJ: Lawrence Erlbaum Associates, 295-336.

Chin, W.W., 2003. PLS-Graph, Version 3.00, Build 1058 (Computer software). Houston, TX: University of Houston.

Chiu, C.-M., Hsu, M.-H., Sunb, S.-Y., Lin, T.-C., and Sun, P.-C., 2005. Usability, quality, value and e-learning continuance decisions. Computers and Education, 45 (4), 399-416.

Chorng-Shyong, O., Jung-Yu, L., and Yi-Shun, W., 2004. Factors affecting engineers' acceptance of asynchronous e-learning systems in high-tech companies. Information \& Management, 41 (6), 795-804. 
Csikszentmihalyi, M., 1993. The evolving self: a psychology for the third millennium. New York: Harper Collins.

Davis, F., Bagozzi, R., and Warshaw, P., 1992. Extrinsic and intrinsic motivation to use computers in the workplace. Journal of Applied Social Psychology, 22, 1111-1132.

Davis, F.D., 1989. Perceived usefulness, perceived ease of use and user acceptance of information technology. MIS Quarterly, 13 (3), 319-339.

Deci, E.L. and Ryan, R.M., 1985. Intrinsic motivation and self-determination in human behaviour. New York: Plenum Press.

Delone, W.H. and Mclean, E.R., 1992. Information system success: the quest for the dependent variable. Information Systems Research, 3 (1), 60-95.

Department for Education and Skills, 2003. Towards a unified E-learning strategy: consultation document, July. London: DFES.

European Commission, 2001. Making a European area of lifelong learning a reality, communication from the commission, November. Brussels: Directorate-General for Education and Culture, Directorate-General for Employment and Social Affairs.

Fishbein, M. and Ajzen, I., 1975. Belief, attitude, intention and behaviour: an introduction to theory and research. Reading, MA: Addison-Wesley.

Ford, M., 1992. Motivating humans: goals, emotions, and personal agency beliefs. Newbury Park, CA: Sage.

Fornell, C. and Larcker, D., 1981. Evaluating structural equation models with unobservable variable and measurement error. Journal of Marketing Research, 18, 3950 .

Frey, B.A. and Birnbaum, D.J., 2002. Learners' perceptions on the value of powerpoint in lectures. Quebec: EDRS.

Gordon, J., 2003. E-learning tagged as best corporate IT investment. E-learning, 4 (1), 8.

Govindasamy, T., 2002. Successful implementation of elearning pedagogical considerations. Internet and Higher Education, 4 (3/4), 287-299.

Hair, J.F., Anderson, R.E., Tatham, R.L., and Black, W.C., 1998. Multivariate data analysis. Upper Saddle River, NJ: Prentice Hall.

Johansen, R. and Swigart, R., 1996. Upsizing the individual in the downsizing organization: managing in the wake of reengineering, globalization, and overwhelming technological change. Reading, MA: Addison-Wesley.

Jöreskog, K.G. and Wold, H., 1982. The ML and PLS techniques for modelling with latent variables: historical and competitive aspects. In: K.G. Jöreskog and H. Wold, eds. Systems under indirect observation, Part $I$. Amsterdam: North-Holland, 263-270.

Laurillard, D.M., 1993. Rethinking university teaching: a framework for the effective use of educational technology. London: Routledge.

Lee, M.K.O., Cheung, C.M.K., and Chen, Z., 2005. Acceptance of internet-based learning medium: the role of extrinsic and intrinsic motivation. Information \& Management, 42 (8), 1095-1104.

Legris, P., Ingham, J., and Collerette, P., 2003. Why do people use information technology? A critical review of the technology acceptance model. Information and Management, 40 (3), 191-204.

Nunnally, J.C., 1978. Psychometric theory. 2nd ed. New York: McGraw Hill.

Pearson, M. and Ford, L., 1997. Open \& flexible PhD study and research, evaluations \& investigations program. Australia: H.E. Div, DEETYA.
Piccoli, G., Ahmad, R., and Ives, B., 2001. Web-based virtual learning environments: a research framework and a preliminary assessment of effectiveness in basic IT skills training. MIS Quarterly, 25 (4), 401-426.

Ravenscroft, A. and Matheson, M.P., 2002. Developing and evaluating dialogue games for collaborative e-learning. Journal of Computer Assisted Learning, 18 (1), 93-101.

Riva, G., 2001. From real to virtual communities: cognition, knowledge, and intention in the worldwide web. In: C.R. Wolfe, ed. Learning and teaching on the world wide web. San Diego, CA: Academic Press, 131-151.

Seyal, A.H., Rahman, M.N.A., and Rain, M.M., 2002. Determinants of academic use of the Internet: a structural equation model. Behaviour \& Information Technology, 21 (1), 71-86.

Thatcher, A. and De La Cour, A., 2003. Small group decision-making in face-to-face and computer mediated environments: the role of personality. Behaviour \& Information Technology, 22 (3), 203-218.

Toral, S.L., Barrero, F., and Martínez-Torres, M.R., 2006. Analysis of utility and use of a web based tool for digital signal processing teaching by means of a Technological Acceptance Model. Computers and education (e-publication ahead of print version).

Toral, S.L., Barrero, F., Martínez-Torres, M.R., Gallardo, S., and Lillo, J., 2005. Implementation of a web-based educational tool for digital signal processing teaching using the technological acceptance model. IEEE Transactions on Education, 48 (4), 632-641.

Venkatesh, V., 1999. Creation of favorable user perceptions: exploring the role of intrinsic motivation. MIS Quarterly, 23 (2), 239-260.

Venkatesh, V. and Davis, F.D., 2000. A theoretical extension of the technology acceptance model: four longitudinal field studies. Management Science, 46 (2), 186-204.

Venkatesh, V. and Morris, M.G., 2000. Why don't men ever stop to ask for directions? Gender, Social Influence, and their Role in Technology Acceptance and Usage Behavior, MIS Quarterly, 24 (1), 115-139.

Venkatesh, V., Speier, C., and Morris, M.G., 2002. User acceptance enablers in individual decision making about technology: toward an integrated model. Decision Sciences, 33 (2), 297-316.

Vijay-Rao, G., 2004. Managing nostalgists: extending information services infrastructure. In: Proceedings of the contributed papers session biomedical and life sciences division, 95th annual conference, 8 June 2004, Nashville, Tennessee.

Wade, W., 1994. Flexible learning and flexibility in course provision. In: J. Martin and J. Darby, eds. The CTISS file. Flexible and distance learning. Oxford: CTISS Publications, University of Oxford, 17.

Webster, J. and Martocchio, J.J., 1996. Microcomputer playfulness: development of a measure with workplace implications. MIS Quarterly, 16 (2), 201-226.

Weiner, L.R., 1993. Digital woes: why we should not depend on software. Reading, MA: Addison-Wesley.

Willcoxson, L., 1998. The impact of academics' learning and teaching preferences on their teaching practices: a pilot study. Studies in Higher Education, 23, 59-70.

Wolfe, C.R., 2001. Learning and teaching on the world wide web. San Diego, CA: Academic Press.

$\mathrm{Wu}$, I.-L. and Wu, K.-L., 2005. A hybrid technology acceptance approach for exploring e-CRM adoption in organizations. Behaviour \& Information Technology, 24 (4), 303-316. 


\section{Appendix 1}

\begin{tabular}{|c|c|c|}
\hline Format & $\begin{array}{l}\mathrm{C} 1 \\
\mathrm{C} 2\end{array}$ & $\begin{array}{l}\text { The material is organised in a flexible way } \\
\text { Some different formats are used in the e-learning tool (text, figures, graphs, videos, etc.) }\end{array}$ \\
\hline Methodology & $\begin{array}{l}\text { C7 } \\
\text { C8 } \\
\text { C9 } 9\end{array}$ & $\begin{array}{l}\text { The objectives and span of the e-learning tool are clearly defined } \\
\text { The duration of the parts of the subject is appropriate } \\
\text { The e-learning tool fits with the content of the subject }\end{array}$ \\
\hline Feedback & $\begin{array}{l}\text { C12 } \\
\text { C14 } \\
\text { C15 } \\
\text { C16 }\end{array}$ & $\begin{array}{l}\text { The feedback of the system is useful for the user } \\
\text { The feedback of the system is given on time } \\
\text { The feedback of the system makes user to continue using it } \\
\text { The e-learning tool allows the user to learn about how much he/she knows about a topic }\end{array}$ \\
\hline User adaptation & $\begin{array}{l}\mathrm{C} 23 \\
\mathrm{C} 25 \\
\mathrm{C} 27 \\
\mathrm{C} 28\end{array}$ & $\begin{array}{l}\text { There are different levels in the e-learning tool according to its complexity, that is, it } \\
\text { allows doing different tasks according to their complexity level } \\
\text { The e-learning tool allows the user to develop his/her initiatives } \\
\text { The e-learning tool allows the user to control his/her improvement } \\
\text { The e-learning tool allows the user to select whatever he/she likes to learn } \\
\text { The e-learning tool keeps the improvement and development of the learning }\end{array}$ \\
\hline Communicativeness & $\begin{array}{l}\text { C29 } \\
\text { C30 } \\
\text { C31 } \\
\text { C } 32\end{array}$ & $\begin{array}{l}\text { The e-learning tool makes easier discussions with teachers } \\
\text { The e-learning tool makes easier discussions with other users } \\
\text { The e-learning tool makes it easier to share new knowledge with other users } \\
\text { The e-learning tool makes it easier to get access to other users' knowledge }\end{array}$ \\
\hline Diffusion & $\begin{array}{l}\text { C33 } \\
\text { C34 } \\
\text { C35 } \\
\text { C36 }\end{array}$ & $\begin{array}{l}\text { I knew the possibilities the e-learning tools offers before I first used it } \\
\text { I knew the technical requirements of the e-learning tool before I first used it } \\
\text { I knew the formative requirements to use the tool before I first used it } \\
\text { The lecturers of the subject encourage students to use the e-learning tool }\end{array}$ \\
\hline Accessibility & $\begin{array}{l}\text { C38 } \\
\text { C39 } \\
\text { C40 }\end{array}$ & $\begin{array}{l}\text { The e-learning tool is accessible according to my own possibilities } \\
\text { The chain of communication is suitable to get access to the e-learning tool } \\
\text { I can easily use the chain of communication that gives me access to the e-learning tool }\end{array}$ \\
\hline Interactivity and control & $\begin{array}{l}\text { C44 } \\
\text { C45 } \\
\text { C46 } \\
\text { C47 }\end{array}$ & $\begin{array}{l}\text { The e-learning tool allows the user to control the rhythm of learning } \\
\text { The e-learning tool allows the user to control the learning sequence } \\
\text { The e-learning tool allows the user to select the contents he/she considers appropriate } \\
\text { The e-learning tool allows the user to select the previous contents whenever he/she } \\
\text { considers appropriate }\end{array}$ \\
\hline Enjoyment & $\begin{array}{l}\text { C48 } \\
\text { C50 } \\
\text { C55 } \\
\text { C56 }\end{array}$ & $\begin{array}{l}\text { The e-learning tool environment is enjoyable } \\
\text { The use of the e-learning tool is a fun activity } \\
\text { The use of the e-learning tool arouses my curiosity } \\
\text { The use of the e-learning tool stimulates my imagination }\end{array}$ \\
\hline Reliability & $\begin{array}{l}\text { C58 } \\
\text { C59 } \\
\text { C60 }\end{array}$ & $\begin{array}{l}\text { The e-learning tool is reliable, as it offers correct information whenever I use it } \\
\text { Whenever I use the e-learning tool, it always works correctly } \\
\text { I trust the system security }\end{array}$ \\
\hline User tools & $\begin{array}{l}\text { C61 } \\
\text { C63 } \\
\text { C64 }\end{array}$ & $\begin{array}{l}\text { The e-learning tool has a search tool that allows access to the contents I need } \\
\text { The e-learning tool allows me to export data } \\
\text { The e-learning tool has a forum of discussion }\end{array}$ \\
\hline Ease of use & $\begin{array}{l}\text { C65 } \\
\text { C66 } \\
\text { C67 } \\
\text { C68 } \\
\text { C70 }\end{array}$ & $\begin{array}{l}\text { Learning to use the e-learning tool has been easy } \\
\text { I feel using the e-learning tool makes it easy to do whatever I like to do } \\
\text { My interaction with the e-learning tool is clear and understandable } \\
\text { I feel the e-learning tool is easy to use } \\
\text { Remembering how to use the e-learning tool is easy }\end{array}$ \\
\hline Perceived usefulness & $\begin{array}{l}\text { C71 } \\
\text { C72 } \\
\text { C73 } \\
\text { C74 } \\
\text { C75 } \\
\text { C76 }\end{array}$ & $\begin{array}{l}\text { The use of the e-learning tool will improve my performance in this subject } \\
\text { The use of the e-learning tool will improve my use of the subject } \\
\text { The use of the e-learning tool would increase my effectiveness in this subject } \\
\text { I feel the e-learning tool is useful in this subject } \\
\text { The use of the e-learning tool will accelerate my learning } \\
\text { The use of the e-learning tool will make learning easier }\end{array}$ \\
\hline Intention to use & $\begin{array}{l}\mathrm{C} 77 \\
\mathrm{C} 78\end{array}$ & $\begin{array}{l}\text { I usually try to review concepts using the e-learning tool } \\
\text { I usually try to compare concepts learned in class and the e-learning view }\end{array}$ \\
\hline Use & $\begin{array}{l}\mathrm{C} 83 \\
\mathrm{C} 84\end{array}$ & $\begin{array}{l}\text { How many times a week do you use the e-learning tool? (as an average) } \\
\text { How many hours a week do you use the e-learning tool? (as an average) }\end{array}$ \\
\hline
\end{tabular}

